\title{
Rugose corals across the Devonian-Carboniferous boundary in NW Turkey
}

Julien Denayer

Acta Palaeontologica Polonica 61 (1), 2016: 51-70 doi:http://dx.doi.org/10.4202/app.00061.2014

An uppermost Famennian (Strunian) coral assemblage has been recovered in the middle part of the Y1lanlı Formation of the Istanbul Zone (Zonguldak and Bartın areas, NW Turkey). In the Bartın area, the studied fossiliferous interval corresponds to a c. 30 m-thick unit of bioclastic to peloidal wackestone to packstone grading to grainstone and including two stromatoporoid biostromes. In the Zonguldak area, $60 \mathrm{~km}$ westward, the bioclastic facies is dominant. The rugose corals are mainly solitary taxa belonging to the genera Campophyllum, Bounophyllum, Amplexocarinia, and ?Metriophyllum, and only one colonial genus occurs: Pseudoendophyllum. This fauna is similar to that documented in Europe. The campophyllids and dibunophyllids are the main component of the uppermost Famennian assemblages in S Belgium, N France, W Germany, NW and S Poland. The endophyllids occur in S Poland, Novaya Zemlya, and in the Ural Mountains. The Istanbul Zone is supposed to be situated in the central part of the Palaeotethys Ocean, along the southern margin of Laurussia during the uppermost Devonian and Carboniferous. The rugose corals indicate some relationship with the eastern part of Laurussia, or that both areas were under a common marine influence at this time. The global Hangenberg event was not recognized in the Turkish localities, except for the disappearance of the corals, occurring less than $19 \mathrm{~m}$ below the Devonian-Carboniferous boundary based on the foraminifers. There is no major facies change through the boundary and the first Carboniferous corals (small Uralinia and Caninophyllum) appear $6 \mathrm{~m}$ above the D-C boundary. The new species Caninophyllum charli sp. nov. is described from the upper part of the lower Tournaisian.

Key words: Rugosa, palaeobiogeography, Hangenberg event, Strunian, Hastarian, Famennian, Tournaisian, Turkey.

Julien Denayer [julien.denayer@ulg.ac.be] Service de Paléontologie animale et humaine, Département de Géologie, Université de Liège, Bat. B18, Allée du Six-Août, SartTilman, B-4000 Liège, Belgium; current address: Integrated Palaeoenvironmental Research Group, School of Earth Sciences, University of Queensland, QLD 4072, St-Lucia, Australia. 
This is an open-access article distributed under the terms of the Creative Commons Attribution License (for details please see creativecommons.org), which permits unrestricted use, distribution, and reproduction in any medium, provided the original author and source are credited.

For Full text $(2,049.5 \mathrm{kB})$ ।

FaF Supplementary file $(151.5 \mathrm{kB})$ 